\title{
Technological, institutional and situational influences on student persistence
}

\author{
Maximus Gorky Sembiring \\ Faculty of Education and Teacher Training, \\ Universitas Terbuka, \\ Jalan Cabe Raya Pondok Cabe, \\ Pamulang, Tangerang Selatan, Indonesia \\ Email: gorky@ecampus.ut.ac.id
}

\begin{abstract}
Understanding plausible variables affecting persistence in open distance learning (ODL) outlooks were explored. It was aimed at exposing associated factors and their attributes, how and in what routines they were interrelated remarked by Universitas Terbuka overseas students. The study was accomplished using exploratory-design. It was qualitatively identified first six variables involved: persistence; epistemological and technological; situational, institutional and dispositional factors. They were quantitatively categorised as the dependent, intervening and independent variables, respectively. Instruments in unified list of queries for review and focus-group discussion (for qualitative) and questionnaires related to the six variables involved (for quantitative) were developed. The ultimate of qualitative approach was aimed at establishing frameworks and hypotheses. Data were processed using structural equation model (SEM) to validate 12 hypotheses; ten were statistically validated. The results confirmed the prominent influence on persistence was technological factor followed by institutional and situational. Variably, persistence was insignificantly affected by epistemological and dispositional.
\end{abstract}

Keywords: open distance learning; ODL; persistence; technological influence; exploratory-design; structural equation model; SEM.

Reference to this paper should be made as follows: Sembiring, M.G. (2018) 'Technological, institutional and situational influences on student persistence', Int. J. Services and Standards, Vol. 12, Nos. 3/4, pp.261-274.

Biographical notes: Maximus Gorky Sembiring is a Professor at the Faculty of Education and Teacher Training of Universitas Terbuka. His research mainly focuses on student support systems for open distance learners. He is currently the Director of the research centre of the university.

This paper is a revised and expanded version of a paper entitled 'Student persistence observed from situational, institutional, dispositional, epistemological and technological influences', presented at The 31st Asian Association of Open Universities Annual Conference, Universitas Terbuka, Yogyakarta, Indonesia, 27-29 September 2017. 


\section{Background}

In their previous reports, Sembiring (2013), Sawitri and Sembiring (2013) and Haliman et al. (2014) reviewed persistence with respect to the Universitas Terbuka students in Indonesia context. The studies were conducted during the year of 2012 up to 2014. In these reports, it was emphasised that student persistence was influenced by situational, institutional, dispositional and epistemological factors. The respondents at these studies were students domiciled in Indonesia as well as some graduates attending commencement in 2012. In these studies, technological aspects were not included yet as one of the main variables that might be leading to student persistence.

Prior to these reports, investigation on student persistence in a much broader sense to various attitudes had also been completed to understand associated factors relatable to persistence which might be encouraged as impediments (Brindley, 1988; Becher, 1989; Garland, 1993). They have made studies and then considered and categorised them as situational, institutional, dispositional and epistemological barriers as number of plausible impacts related to student persistence. Newly, technological control was also included as an influential factor to student persistence particularly in the Universitas Terbuka ambiance within the frame of an open distance learning (ODL) outlooks with slightly different arrangement substantially and methodically (Sembiring, 2015; Ibrahim et al., 2016).

Despite many institutions had tried toward the goals of achieving higher completion rate (Brindley, 1995), it was reasonable logical to say that most of them were still losing students than they would like to. It remains as the fact that student persistence is still one of central issues in ODL perspective. This implies that with the growth of ODL came the problem of exceedingly high attrition rates (Parker, 2003).

To date, Universitas Terbuka (2017) has 40 regional offices all over Indonesia to serve 297,897 students worldwide; and 1,976 of them were resided overseas. Regional Office for Overseas Students established to manage those students scattered out in 34 countries with 51 cities for examination locations. In terms of achievement, having 1,976 students in 2016 was certainly blameless since within these four years back there was always slight improvement in student body. Nonetheless, it was still below the initial target, namely 3,000 students for 2016 academic year. There are several motives on why the target was not achieved yet. One of them is related to the question of student persistence primarily within the ODL setting.

It was then fascinating to explore what were the reasons for overseas students to persist with respect to Universitas Terbuka context. The main objective of the study was therefore to understand and discover associated plausible factors as the significant influences and affecting persistence, including their associated characteristics. It was also of interests to visualise on how they are all interrelated one and the others and in what behaviour persistence is interrelated to situational, institutional, dispositional, epistemological and technological factors with all attributes engaged.

\section{Design and the methodology}

Regional Office for Overseas Students, for simplicity reasons, managed student registration twice per year and limited to six out of 34 programs in bachelor degree. In 2016 for instance, there were 1,976 students registration; they were all the population of 
this study. Exploratory-design, as part of mixed methods, was utilised where qualitative procedure implemented first and then sequentially followed by the quantitative series (Creswell and Clark, 2011). Instruments in the form of unified list of queries and questionnaires were developed with respect to the six variables involved as inspired by Tjiptono and Chandra (2011). The lists of queries were established first for qualitative purpose with intent to construct the conceptual and operational frameworks through review, interview and/or focus-group discussion sessions. Four recognised experts as resource persons for qualitative approach were purposely chosen. The ultimate of the conceptual and operational frameworks lead to establishing the hypotheses of the study and then statistically scrutinised afterwards. Eligible respondents for quantitative approach to acquiring data were randomly selected as suggested by Cochran (1977) and Sugiyono (2012).

The questionnaires as a continuance of and relatable to the qualitative frame were distributed (750 sets were provided) to gather data from respondents. The population was those 1,976 students domiciled overseas. Survey was conducted by following Fowler (2014). Three hundred six of 750 distributed questionnaires were completely returned and finally processed. Structural equation model (SEM) was then utilised to scrutinise and analyse the obtained data in conjunction with discovering the power of relations among variables and dimensions engaged (Hair et al., 2009; Sugiyono, 2012). The results were arranged in figures and tables completed under Lisrel version 8.80 (Wijayanto, 2008).

\section{Conceptual and operational frameworks}

Here, the Tinto's as well as Bean and Metz's model initiated earlier by Tinto (1975) and elaborated by Bean and Metzner (1985) were considered as the theoretical groundwork to establishing the frameworks of the inquiry. Study of persistence in ODL setting was seen as an important aspect. Rovai (2003) pointed out there was no simple formula to understand student persistence since it was complicated responses to multiple factors and being unique to most of adult learners. It was not plausible to attribute attrition to only any single factor. There were numerous factors thoroughly mixed up, including interactions amongst related factors engaged. This eventually leads to the preposition that understanding factors influencing student persistence especially at the regional office level in Universitas Terbuka context becomes crucial.

Study on student persistence at an earlier stage integrated an input-process-output perspective as the preliminary setting. Talent development frame was familiarised and student involvement in higher education resulted in the development of certain talent inherent to student and the system (Astin, 1970). There was a focus on establishing foundation for further studies on variables that shaping student persistence. It was suggested that when students become totally involved, the level and intensity of their involvement in institutional ambiance will affect eagerness to persist in the program that they engrossed. Later, the involvement theory was introduced where students learn by becoming really involved and learning is therefore an actual reason to persist.

Various theoretical models of persistence had emerged and they were perceived based on psychological paradigms. Determinants of successful student persistence can be broken down into experiences: 
1 prior to entering university along with individual traits

2 during in the university; there were several details highly relevant on this experiences.

To certain extent, devotion upon personal goal viewed from institutional perspective relevant to dropout decision. Furthermore, family background, individual attributes and pre-university education for examples were clearly part of commitment of personal goal viewed from institutional standpoint. In other words, personal goal commitment forms academic performance. In addition, institutional commitment inspires social integration in peer and faculty interaction. Performance and intellectual development were connected with peer and faculty interaction (Tinto, 1975; Bean and Metzner, 1985; Bean, 2001).

Based on those elaborative core explained, they were then developed into student attrition model. The model illustrated student persistence, as the dependent variable, was affected by five independent factors (Rovai, 2003). Those factors consisted of previous educational background and other labelling components, including environmental and academic and/or psychological outcomes. Attributes of academic factor consisted of study preference, advising, absenteeism, course availability, and the relevance of available program. Such background and other defining factors comprised of age, status of residence, educational objective, ethnicity and previous grade point average (GPA). Environmental factor might involve financial aspect, employment status, family responsibility, outside encouragement and opportunity to recognition of prior learning. Academic outcome enclosed current GPA. Psychological outcomes might also include utility, stress, satisfaction, goal and related institutional commitment.

Garland (1993) clarified that persistence was affected by several major points. They were described as situational, institutional, dispositional and epistemological barriers. Situational impediment reduces from person life situation. Institutional obstacle involved administrative and certain academic services. Dispositional hindrance was related to the psychological and social natures. Likewise, epistemological constraint was interrelated with the difficulty level of a subject matter. These four main controls were considered to be having effects on persistence. They were firmly relevant to Universitas Terbuka condition in Indonesia context (Haliman et al., 2014).

To illustrate in a more clearly way, variables involved and the dimensions attached to them will be comprehensively described further for this study. Conceptually, as also highlighted by Bean (2001), student persistence was defined as student actively registers each semester until they pass all the courses taken as required by the university, and they also finally graduated on time. It was operationally referred to as student engaged regularly in registration, tutorials activities, exams and auxiliary activities that support their academic achievement through various study group activities. Besides, personal attributes including concern in career related to technology, time and effort invested, and perceived utility of learning relevant to persistence, such as relevancy of courses to professional needs, satisfaction with courses and program, and ties between coursework and job promotion. This will improve completion and graduation rates especially in fully online programs (Yang et al., 2017). Persistence, according to Chiyaka et al. (2016), also related to some key institutional characteristics. With the help of multivariable regression approach, they found that aspects namely graduation and default rates as well as college type were positively associated with student persistence. Furthermore, graduation rate was discovered to be the most influential factor with respect to retention rate. 
Conceptually, as prompted by Reyes-Rueda (2011), personal or situational variable was student environmental factors possibly affect their behaviour to continue the study. In this regard, situational influence is operationally explained as various aspects that potentially interfere the success of their study. This was particularly related to dealing with student environment, time management, financial aspect to support student fees and information and communication technology (ICT) concerns. Similarly, dispositional in the conceptual stage was described as an internal factor which might influence their behaviour in terms of intelligence or agility. It was operationally then justified here as the ability to recognise knowledge on goals, multiple roles, learning styles and specific psychological aspect, including adult pride issue.

Institutional characteristic, again as indicated by Rovai (2003), was conceptually defined as the kind of services given to students soon after an admission stage. Operationally, issues on scheduling procedures, instructional design problems and related institutional assistance were defined as the institutional influences or barriers. In the conceptual framework, epistemological influence was defined as a reflection of congruence between student cognitive, affective characteristics and the nature of the knowledge presented in the subject matter (Garland, 1993). For operational needs, the portions on academic content, the gap on the know-how, individual interest and prerequisite that interferes student accomplishment were articulated as the epistemological attributes.

In the conceptual level, technological factor was defined as a prerequisite of being able to enter and accommodate ODL delivery mode using electronic media (Sembiring, 2017). Anyone who is involved in ODL ought to recognise this requirement. In operational sense, technological influences in relations to student persistence were associated with the availability, accessibility, affordability and comfortableness connotation. Now, ODL and technology can no longer be separated, they were an integrated entity in this ICT era related to learning.

Table 1 Variables and dimensions of the study

\begin{tabular}{|c|c|c|c|}
\hline No. & Variables & Dimensions & Notes \\
\hline 1 & Persistence $(\mathrm{Y})$ & $\begin{array}{l}\text { Re-registration }\left(\mathrm{Y}_{1}\right) \text {, tutoring activities }\left(\mathrm{Y}_{2}\right) \text {, } \\
\text { examination }\left(\mathrm{Y}_{3}\right) \text {, participation in study } \\
\text { group }\left(\mathrm{Y}_{4}\right)\end{array}$ & \multirow{2}{*}{$\begin{array}{l}\text { Six main variables: } \\
\mathrm{Y}, \mathrm{X}_{1-3} \text { and } \mathrm{X}_{4-5} \text { are } \\
\text { the dependent, } \\
\text { independent and } \\
\text { moderating variables, } \\
\text { respectively. }\end{array}$} \\
\hline 2 & Situational $\left(\mathrm{X}_{1}\right)$ & $\begin{array}{l}\text { Student environment }\left(\mathrm{X}_{11}\right) \text {, roles }\left(\mathrm{X}_{12}\right) \text {, } \\
\text { financial support }\left(\mathrm{X}_{13}\right) \text {, general study skills } \\
\left(\mathrm{X}_{14}\right)\end{array}$ & \\
\hline 3 & Institutional $\left(\mathrm{X}_{2}\right)$ & $\begin{array}{l}\text { Institutional procedures }\left(\mathrm{X}_{21}\right) \text {, schedule } \\
\left(\mathrm{X}_{22}\right) \text {, instructional design problems }\left(\mathrm{X}_{23}\right) \text {, } \\
\text { academic and non-academic counselling } \\
\left(\mathrm{X}_{24}\right)\end{array}$ & \multirow{4}{*}{$\begin{array}{l}\text { Each variable has } \\
\text { four dimensions and } \\
\text { each dimension is } \\
\text { measured by } \\
\text { three questions; } \\
\text { Likert scale (1 to 5). } \\
\text { Total questions: } 72 \text {. }\end{array}$} \\
\hline 4 & Dispositional $\left(\mathrm{X}_{3}\right)$ & $\begin{array}{l}\text { Personal goal }\left(\mathrm{X}_{31}\right) \text {, multiple roles }\left(\mathrm{X}_{32}\right) \text {, } \\
\text { learning style }\left(\mathrm{X}_{33}\right) \text {, adult pride }\left(\mathrm{X}_{34}\right)\end{array}$ & \\
\hline 5 & Epistemological $\left(\mathrm{X}_{4}\right)$ & $\begin{array}{l}\text { Content-wise }\left(X_{41}\right) \text {, prerequisite knowledge } \\
\left(X_{42}\right) \text {, personal interest }\left(X_{43}\right) \text {, expectancy } \\
\text { gap }\left(X_{44}\right)\end{array}$ & \\
\hline 6 & Technological $\left(\mathrm{X}_{5}\right)$ & $\begin{array}{l}\text { Availability }\left(X_{51}\right) \text {, accessibility }\left(X_{52}\right), \\
\text { affordability }\left(X_{53}\right) \text {, comfortableness }\left(X_{54}\right)\end{array}$ & \\
\hline
\end{tabular}


Having described all related theoretical groundworks and then defined them in the conceptual and operational levels, they are all simply summarised as exhibited in Table 1. Based on this summary (Table 1), the operational framework is graphically established as a point of reference to develop instruments for quantitative purposes in the form of questionnaire as well as the hypotheses of the study that will be statistically assessed afterward.

Having determined variables, dimension and related conceptual and operational definitions, the qualitative approach comes to the proposition in the configuration of unified hypotheses. They are systematically illustrated in Figure 1 and denoted as the initial operational framework of this study. This framework will be statistically scrutinised later under SEM with respect to the results of hypotheses testing and the loading factors analysis to deduce quantitative upshot as a part of quantitative procedure.

Figure 1 The initial operational framework

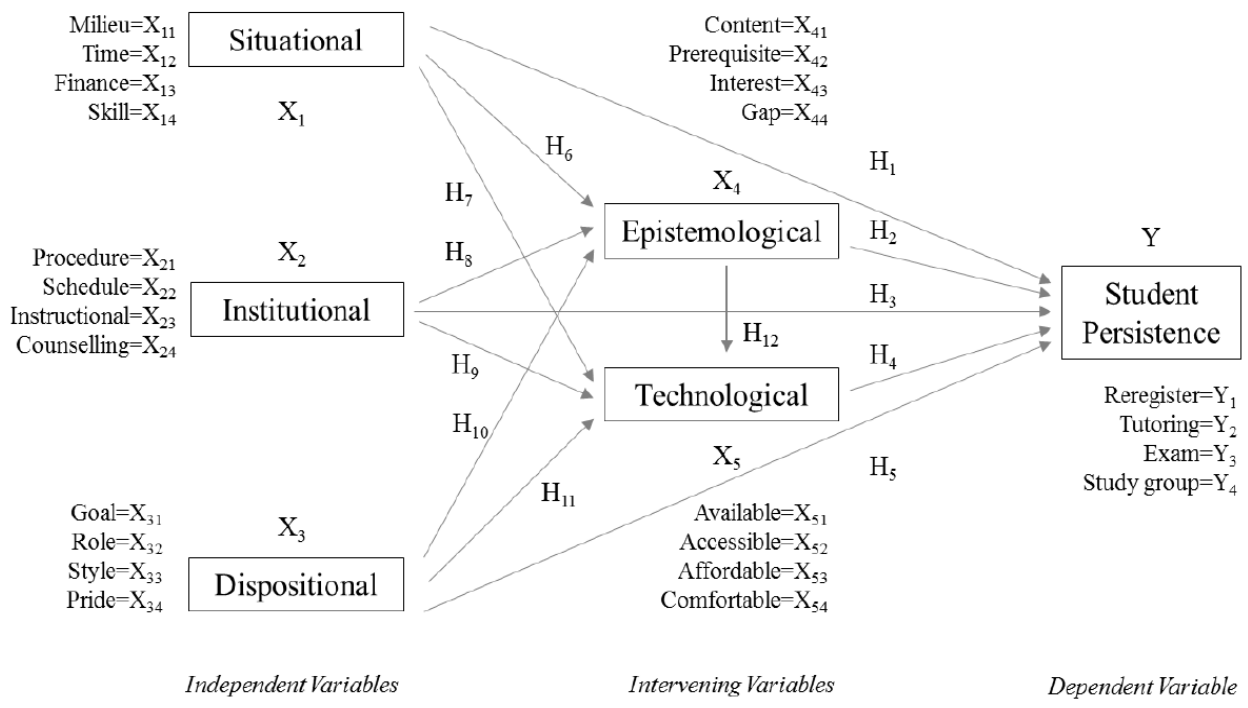

Figure 1 highlighted 12 hypotheses involved, consisting of five primary and seven secondary hypotheses. The primary hypotheses: student persistence (Y) is directly and positively affected by situational $\left(\mathrm{H}_{1}\right)$, epistemological $\left(\mathrm{H}_{2}\right)$, institutional $\left(\mathrm{H}_{3}\right)$, technological $\left(\mathrm{H}_{4}\right)$ and dispositional $\left(\mathrm{H}_{5}\right)$ influences. The secondary hypotheses: epistemological $\left(\mathrm{X}_{4}\right)$ is affected by situational $\left(\mathrm{H}_{6}\right)$, institutional $\left(\mathrm{H}_{8}\right)$ and dispositional $\left(\mathrm{H}_{10}\right)$ influences; besides, technological $\left(\mathrm{X}_{5}\right)$ is affected by situational $\left(\mathrm{H}_{7}\right)$, institutional $\left(\mathrm{H}_{9}\right)$ and dispositional $\left(\mathrm{H}_{11}\right)$ influences; and technological $\left(\mathrm{X}_{5}\right)$ is also affected by epistemological $\left(\mathrm{H}_{12}\right)$ influence.

Next, we come to the implementation and will be elaborated further by conforming the quantitative result to the associated argument and then compared them to qualitative framework established earlier. 


\section{Results and discussion}

Before elaborating the results in a more detail, it is constructive to recognising that the validity and reliability of the instrument were methodically confirmed. Besides, normality of the data was also verified by the statistical tool used. Based on these basic preliminary results, it can be determined that the next step of data analysis processes and deducing inferential upshots can be then proceeded.

Prior to corresponding on the result, it is useful to elucidate the characteristics of students as eligible respondents of the study that completing the questionnaires (Table 2). The study was conducted at the Regional Office for Overseas Students jurisdiction. Population was 1,976 students enrolled in 2016. They were mostly living in Hong Kong, Malaysia, Singapore, South Korea and Taiwan. They were registered at least a semester beforehand so they have had experiences on the program they involved in. This is to provide better perspective on the context of the study before discussing the results and inferring the remarks.

Table 2 Respondents characteristics

\begin{tabular}{|c|c|c|c|c|c|}
\hline \multirow{2}{*}{$\begin{array}{l}\text { Study } \\
\text { group \% }\end{array}$} & Hong Kong: 22 & Taiwan: 21 & South Korea: 26 & Malaysia: 18 & Singapore: 14 \\
\hline & Middle East: 00 & Europe: 00 & USA: 00 & Australia: 00 & Others: 1 \\
\hline $\begin{array}{l}\text { Study } \\
\text { program }\end{array}$ & $\begin{array}{c}\text { English } \\
37 \%\end{array}$ & $\begin{array}{c}\text { Management } \\
30 \%\end{array}$ & $\begin{array}{c}\text { Communication } \\
23 \%\end{array}$ & $\begin{array}{c}\text { Business } \\
9 \%\end{array}$ & $\begin{array}{c}\text { Others } \\
1 \%\end{array}$ \\
\hline \multirow{2}{*}{$\begin{array}{l}\text { Semester } \\
\text { profession }\end{array}$} & $1=8 \%$ & $2=39 \%$ & $3=22 \%$ & $4=25 \%$ & $5^{+}=6 \%$ \\
\hline & Public: $1 \%$ & Private: $3 \%$ & Industry: $24 \%$ & $\begin{array}{c}\text { Informal: } \\
64 \%\end{array}$ & Others: $8 \%$ \\
\hline GPA $(\%)$ & $0.00-1.99: 11$ & $2.00-2.49: 46$ & 2.50-2.99: 31 & $3.00-3.49: 8$ & $3.50-400: 4$ \\
\hline Age (year) & 19-24: $29 \%$ & 25-29: $38 \%$ & $30-34: 20 \%$ & $35-39: 9 \%$ & $\geq 40: 4 \%$ \\
\hline Gender (\%) & Female: 69 & Male: 31 & Status $(\%)$ & Married: 42 & Unmarried: 58 \\
\hline
\end{tabular}

Generally, the respondents have full time job; implied they were not full time students. Besides, more than $90 \%$ of them already had at least two consecutive semester experiences as student at the Universitas Terbuka. This implied that they were familiar enough with the system. About $58 \%$ of them were 25 to 34 year of age; implied less than $30 \%$ were in the age of regular students. In other words, most of them can be categorised as adult learners, non-full time students, and therefore sensitively retained adult pride senses in terms of dispositional influences. Moreover, none of them were enrolled in the Faculty of Education. These characteristics were relatively different from most students living in Indonesia. The vast majority of students in Indonesia were teachers. Besides, most of them were relatively matured in terms of age (35-44 year of age) and they study in Faculty of Education and Teacher Training. While overseas students enrolled in the other faculties (Faculty of Economics, Faculty of Law, Social and Political Science and Faculty of Mathematics and Natural Sciences). Now, let us move to the SEM outputs comprising the results of hypotheses and the loading factors analysis of the tested framework. It also included the goodness of fit of the tested operational framework. They are all exhibited in Figure 2 and Table 3. 
Figure 2 Results of hypotheses and the loading factors

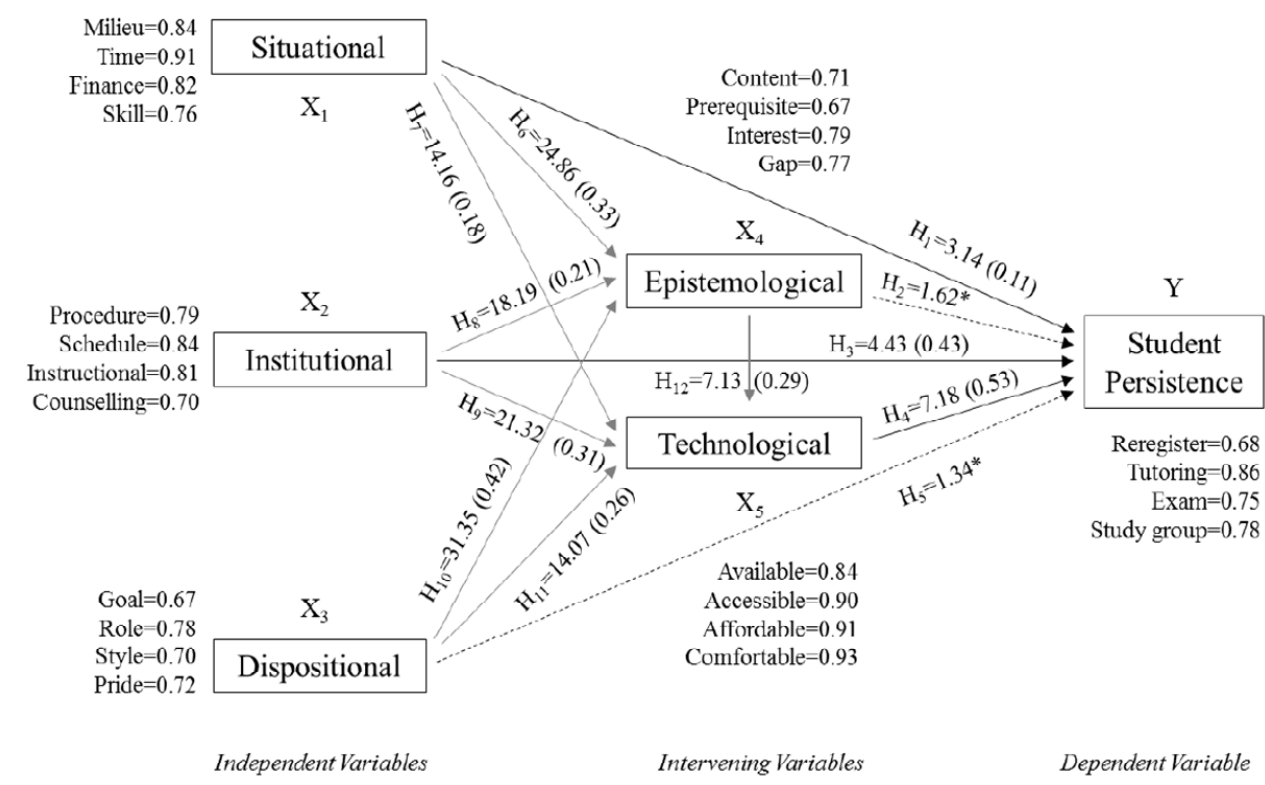

Note: $*$ Not validated as the $\mathrm{t}_{\text {value }} \leq 1.96(\alpha=5 \%)$.

Figure 2 obviously explicated that ten out of 12 hypotheses developed and established were directly and positively validated by the analysis. They are:

1 situational to persistence $\left(\mathrm{H}_{1}=3.14\right)$

2 institutional to persistence $\left(\mathrm{H}_{3}=4.43\right)$

3 technological to persistence $\left(\mathrm{H}_{4}=7.18\right)$

4 situational to epistemological $\left(\mathrm{H}_{6}=24.86\right)$

5 institutional to epistemological $\left(\mathrm{H}_{8}=18.19\right)$

6 dispositional to epistemological $\left(\mathrm{H}_{10}=31.35\right)$

7 situational to technological $\left(\mathrm{H}_{7}=14.16\right)$

8 institutional to technological $\left(\mathrm{H}_{9}=21.32\right)$

9 dispositional to technological $\left(\mathrm{H}_{11}=14.07\right)$

10 epistemological to technological $\left(\mathrm{H}_{12}=7.13\right)$, as the $\mathrm{t}_{\text {value }} \geq 1.96$ (for $\alpha=5 \%$ ).

This implied that there are two hypotheses that were not significantly validated by the analysis, as the $t_{\text {value }} \leq 1.96$ (for $\alpha=5 \%$ ). They are epistemological to persistence $\left(\mathrm{H}_{2}=1.62\right)$ and dispositional to persistence $\left(\mathrm{H}_{5}=1.34\right)$.

After looking at the hypotheses, the next output was on the method of estimated model to discern the loading factors measurement of the initial operational framework. This result should be revealed to perceive conformation on the level of influential powers amongst variables and dimensions engaged as well as their behaviours. This is to assess whether the initial model, that is the framework established and assessed, was statistically 
validated and practically accepted by the analysis. If we noticed on the output of the statistical processes, illustrated in Figure 2, at least there were five essential remarks need to be carefully particularised prior to deducing the final remarks.

First, three of the main variables positively and directly affected student persistence. They are orderly as follows:

1 technological $\left(\mathrm{X}_{4}=0.53\right)$

2 institutional $\left(\mathrm{X}_{2}=0.43\right)$

3 situational $\left(\mathrm{X}_{1}=0.11\right)$ factors.

These upshots were partly supported by Garland (1993) and Sembiring (2015) particularly on the technological, institutional and situational controls. This specific output provokes us to believe that barriers to persistence in ODL to certain extent can be controlled. How we can control them? By providing various support services with the help of appropriate technological supports. Given services provided are institutionally dependable in one hand and most of students are personally well-prepared with ODL mode on the other hands then technological influences might effectively control barriers on epistemological and dispositional in the frame of ODL. This is a great evidence for stakeholders to reflect on. High completion and low dropout rates are optimistically no longer stay as a big problem for they can be appropriately and harmoniously mediated by technological controls in ODL outlooks.

Second, on the influencing dimensions represent technological influence. They were found and ordered as follows:

1 comfortable $\left(\mathrm{X}_{54}=0.93\right)$

2 affordable $\left(\mathrm{X}_{53}=0.91\right)$

3 accessible $\left(\mathrm{X}_{52}=0.90\right)$

4 available $\left(\mathrm{X}_{51}=0.84\right)$.

These four dimensions were absolutely pertinent to dealing with technological provision that support student persistence positively. On the influencing dimensions as a representation of institutional influence, they were found and ordered as follows:

1 schedule $\left(\mathrm{X}_{21}=0.84\right)$

2 instructional design problems $\left(\mathrm{X}_{23}=0.81\right)$

3 institutional procedures $\left(\mathrm{X}_{21}=0.79\right)$

4 counselling services $\left(X_{24}=0.70\right)$.

These four dimensions were crucial factors and should be cautiously provided and maintained by the university with respect to student persistence. On the influencing dimensions that representing situational influence, they were found and ordered as follows:

1 time management $\left(\mathrm{X}_{12}=0.91\right)$

2 personal environment $\left(\mathrm{X}_{12}=0.84\right)$

3 related financial support $\left(\mathrm{X}_{13}=0.82\right)$ 
4 IT skills $\left(\mathrm{X}_{14}=0.76\right)$.

These implied that students should be repeatedly cautioned that they must literate and being alert on the technological advancement especially related to their educational needs. Additionally, they should be able to effectively manage their own time as they were having multiple roles and also as adult learners with intrinsic adult pride. This however can not be exclusively controlled by the institution.

Third, despite epistemological and dispositional influences were statistically excluded by the analysis, students placed influencing dimensions representing epistemological factor orderly as follows:

1 personal interest within the program $\left(\mathrm{X}_{41}=0.79\right)$

2 substantial expectancy gap $\left(\mathrm{X}_{44}=0.77\right)$

3 the content of subject matter $\left(\mathrm{X}_{41}=0.71\right)$

4 prerequisite knowledge of the subject $\left(\mathrm{X}_{42}=0.67\right)$.

Correspondingly, students positioned influencing dimensions representing dispositional influence orderly as follows:

1 multiple roles $\left(\mathrm{X}_{32}=0.78\right)$

2 adult pride $\left(\mathrm{X}_{34}=0.72\right)$

3 individual learning style $\left(\mathrm{X}_{33}=0.70\right)$

4 personal goal $\left(\mathrm{X}_{31}=0.67\right)$.

This positive evident was quite relevant to Sembiring (2017). To some extends, this effect can be explained as the respondents (refer to Table 2) were domiciled overseas (Hong Kong, Singapore, South Korea, Taiwan and Malaysia) in the country where ICT facilities are quite advanced compared to general condition of most students domiciled within the country.

Again, the epistemological and dispositional barriers seem to be substituted by technological, institutional and situational (personal) influences for most of those overseas students. These also implied that epistemological and dispositional influences were real and exist but they did not affect most of students domiciled overseas. Now, it might no longer be problems on condition that students were able to manage their time productively and the university at the same time is able to reassure associated services needed by students that were technologically friendly, affordable, accessible and available at all level of services.

Fourth, it was proper to observe the details of relations between independent and intervening variables related to and the rank of each variable engaged with respect to student persistence as the dependent variable. Epistemological $\left(\mathrm{X}_{4}\right)$ was respectively influenced by dispositional $\left(\mathrm{X}_{3}=0.42\right)$, situational $\left(\mathrm{X}_{1}=0.33\right)$ and institutional $\left(X_{2}=0.21\right)$ factors. Serially, technological $\left(X_{5}\right)$ was also influenced orderly by institutional $\left(\mathrm{X}_{3}=0.31\right)$, dispositional $\left(\mathrm{X}_{2}=0.26\right)$ and situational $\left(\mathrm{X}_{1}=0.18\right)$. Two essential aspects need to be explained in more detail further here. First, despite student persistence was insignificantly affected by dispositional but to certain extent it was affected indirectly through the intervening variable (technological influence). Second, conversely, student persistence was not affected both directly and/or indirectly 
by dispositional and epistemological factors simultaneously. It entails that statistically there were insignificant relations on dispositional and epistemological to student persistence despite epistemological influence was affected by dispositional and technological influence was influenced by epistemological factor.

This result was quite anomalous as most previous comparable study conducted in the Universitas Terbuka context with similar framework but slightly different respondents tend to show that student persistence influenced by dispositional and epistemological, either directly or indirectly (Sawitri and Sembiring, 2013; Haliman et al., 2014). After implementing further secondary observation, there were two main arguments can be discovered on how this difference did take place. First, in the previous study, most of respondents can be categorised as adult learners and they took courses after working for around 10 to 15 years. In other words, they were not in the learning mode conditions for such a long period of time. This condition pushed them to acclimatised first to a learning mode that is in ODL atmosphere. It takes more time for them to readjust not only for prerequisite knowledge (as part of epistemological factor) but also to familiarise a new style of learning as independent learners and matured students (as part of dispositional factor). It really needs further comprehensive inquiry prudently implemented to find reasons how and why this quantitative upshot conversely resulted compared to the previous equivalent studies including to the established qualitative framework of this study apart from what was previously explained.

Fifth, it was conclusively enlightening to disclose the rank of dimensions on the dependent variable, namely student persistence (Y). In the operational framework, it was initially defined that persistence was characterised by students doing re-registration processes regularly, active participation in the tutoring services, attending exam with intent and fully getting involved in the study group activities. Students empirically identified that the most critical dimension related to persistence was active participation in the tutorial programs $\left(\mathrm{Y}_{2}=0.86\right)$. The other identified dimensions were successively involvement in the study group $\left(\mathrm{Y}_{4}=0.78\right)$, attending exams enthusiastically $\left(\mathrm{Y}_{3}=0.75\right)$ and doing re-registration consistently $\left(\mathrm{Y}_{1}=0.68\right)$. The keywords on persistence behold by most of overseas students of the university were active participation both in the tutorial and study group activities.

The study group activities were not always relatable to academic activities although it has implicit effect to their spirit to accomplish study on schedule accordingly. It might involve non-academic activities mostly in the social context. Meeting with friends coming from similar cultural background and having social engagement after being highly committed to their full time job, out of the country for some time and being separated far away from home and family for some years.

It appears that this kind of spirit was pertinent in relations to student persistence perceived from respondent's characteristics to complement the tutorial activities. Tutorial activities are also referred to as face to face (classroom tutorials) supplementary to the online tutorials. In other words, even technological factor might positively be mending the academic gap but face to face interaction is still considered to be pertinent as compared to the technological influences. This is a part of social needs as socially human being at the same time.

Now, we consult to the goodness of fit of the tested framework viewed from statistical angle. This is vital to recognise whether or not the framework were reliable to be applied as a point of reference to inferentially deduce the final remarks (Table 3 ). 
Table 3 Goodness of fit of the framework

\begin{tabular}{lccc}
\hline Goodness of fit & Cut-off values & Results & Notes \\
\hline Root mean square residual (RMR) & $\leq 0.05$ or $\leq 0.1$ & 0.088 & Good fit \\
Root mean square error of approximation (RMSEA) & $\leq 0.08$ & 0.077 & Good fit \\
Goodness of fit (GFI) & $\geq 0.90$ & 0.950 & Good fit \\
Adjusted goodness of fit index (AGFI) & $\geq 0.90$ & 0.940 & Good fit \\
Comparative fit index (CFI) & $\geq 0.90$ & 0.950 & Good fit \\
Normed fit index (NFI) & $\geq 0.90$ & 0.930 & Good fit \\
Non-normed fit index (NNFI) & $\geq 0.90$ & 0.980 & Good fit \\
Incremental fit index (IFI) & $\geq 0.90$ & 0.960 & Good fit \\
Relative fit index (RFI) & $\geq 0.90$ & 0.950 & Good fit \\
\hline
\end{tabular}

The values were all providentially dependable as they were greater than that of standard error of measurements and the RMSEA was less than required cut-off value. These results implied that from statistical point of view the validity and reliability of the instruments as well as the normality of the data gathered satisfied the required necessity. If we notice the notes in Table 3, it implied that the statistical output is methodologically reliable to be used as proper consequences. This also entailed that from methodological direction, referring to the qualitative results previously obtained, the tested framework was just about perfectly approved by the quantitative end despite the two influences (epistemological and dispositional) were statistically indirectly excluded by the analysis.

\section{Concluding remarks}

Perceptually, Universitas Terbuka overseas students regarded technological, institutional and situational influences as three viable obstructions respectively to their persistence. This outcome was validated by apprising observed survey of 306 students in 2016 academic year mainly domiciled in Hong Kong, Singapore, Malaysia, South Korea and Taiwan (Table 2). Partly, this result is comparable with the effects implied by Parker (2003) and Ojokheta (2010). Surprisingly, epistemological and dispositional factors were excluded as the two main influences on student persistence. This implied that further enquiry needs to be carried out to uncover plausible substantial motives how and why the different ending contrariwise was transpired. This is crucial as several prior finding suggested content-wise (dimension of epistemological) and multiple roles (dimension of dispositional) had direct effects to persistence. By conducting the more comprehensive investigation, it will give positive impact for other institutions to be adopted in ODL perspectives.

This finding however can still be used to measure outcomes of those decisions in aggregate. Faculty and management are under increasing pressure to demonstrate direct evidence of student learning and the impact of their interactions within the frame of persistence. While every element of the university is focused on student side, there should be certain division or group of staff with initiatives rely on and contribute to the theory and practice of persistence. This experience will be valuable not only for Universitas Terbuka but also to other universities with comparable characteristics. Correspondingly, it is crucial for the university to externally gear up existing and 
prospective students to apprehend these outcomes. This is to prepare more students realise how to confidently succeed in ODL mode of learning. Internally, the management shall get ready for relevant support mechanism to avoid non-persistence students in the future due to technical, institutional and situational factors.

Lastly, further inquest on persistence is obviously required to be implemented on a regular-base with appropriate improvement both in the theoretical and operational framework as well as in the methodological quality. This is to adopt possible shifts in student need and aspiration as well as to ensure higher education is open to all through flexible quality education is empirically occurred. This is related to the tagline of the university (Universitas Terbuka, 2014). The same dreams that previously also prompted by Astin (1985) and Bean (2001).

\section{References}

Astin, A. (1970) 'College influence: a comprehensive view', Contemporary Psychology, Vol. 15, No. 9, pp.543-546.

Astin, A. (1985) Achieving Educational Excellence, Jossey-Bass, San Francisco, USA.

Bean, J. and Metzner, B. (1985) 'A conceptual model of nontraditional undergraduate student attrition', Review of Educational Research, Vol. 55, No. 4, pp.485-650.

Bean, P.B. (2001) College Student Retention-Defining Student Retention, a Profile of Successful Institutions and Students, Theories of Student Departure, The National Center for Educational Statistics [online] http://education.stateuniversity.com/pages/1863/College-Student-Retention. html (accessed 21 January 2018).

Becher, T. (1989) Academic Tribes and Territories: Intellectual Enquiry and the Culture of Disciplines, Open University Press, Milton Keynes, England.

Brindley, J.E. (1988) 'A model of attrition for distance education', in Sewart, D. and Daniels, J.S. (Eds.): Developing Distance Education, pp.131-137, International Council for Open and Distance Education (ICDE), Oslo, Norway.

Brindley, J.E. (1995) 'Learners and learner services: the key to the future in distance education', in Roberts, J.M. and Keough, E.M. (Eds.): Why the Information Highway: Lessons from Open Distance Learning, pp.102-125, Trifolium, Toronto, Canada.

Chiyaka, E.T., Sithole, A., Manyanga, F., McCarthy, P. and Bucklein, B.K. (2016) 'Institutional characteristics and student retention: what integrated postsecondary education data reveals about online learning', Online Journal of Distance Learning Administration, Summer, Vol. 19, No. 2, pp.1-9 [online] http://www.westga.edu/ distance/ojdla/ (accessed 18 February 2018).

Cochran, W.G. (1977) Sampling Techniques, 3rd ed., John Wiley \& Sons, New York, USA.

Creswell, J.W. and Clark, V.L.P. (2011) Designing and Conducting Mixed Methods Research, 2nd ed., Sage Publication, Inc., Los Angeles, USA.

Fowler Jr., F.J. (2014) Survey Research Methods, 5th ed., Sage, Los Angeles, USA.

Garland, M.R. (1993) 'Student perceptions of the situational, institutional, dispositional and epistemological barriers to persistence', Distance Education, Vol. 14, No. 2, pp.181-198.

Hair, Jr., J.F., Black, W.C., Babin, B.J. and Anderson, R.E. (2009) Multivariate Data Analysis with Readings, 7th ed., Prentice Hall Inc., New Jersey, USA.

Haliman, H., Susanty, E. and Sembiring, M.G. (2014) 'Intent to persist perceived by overseas students of Universitas Terbuka', paper presented at the 28th Asian Association of Open Universities Annual Conference, Open University of Hong Kong, Hong Kong, 28-31 October [online] http://www.stou.ac.th/lcm/Uploadfile/AAOU\%202014\%20Proceedings.pdf. 
Ibrahim, N., Sembiring, M.G. and Sapriati, A. (2016) 'Investigating satisfaction with blended learning in Universitas Terbuka framework', paper presented at The Educational Technology World Conference, Bali, Indonesia, 31 July-3 August [online] http://seminars.unj.ac.id/etwc.

Ojokheta, K. (2010) 'A path-analytic study of some correlates predicting persistence and student's success in distance education in Nigeria', Turkish Online Journal of Distance Education, Vol. 11, No. 1, pp.181-192.

Parker, A. (2003) 'Identifying predictors of academic persistence in distance education', USDLA Journal, Vol. 17, No. 1, pp.55-62 [online] http://www.usdla.org/html/journal/ JAN03_Issue/article06.html.

Reyes-Rueda, J. (2011) Describe the Role of Dispositional and Situational Factors in Explaining Behavior, SIS IB Psychology [online] http://psychology.geckos.sis.org.cn/2011/09/describethe-role-of-dispositional-and-situational-factors-in-explaining-behavior/ (accessed 17 January 2018).

Rovai, A.P. (2003) 'In search of higher persistence rates in distance education online program', Internet and Higher Education, Vol. 6, No. 2003, pp.1-16.

Sawitri, H.H. and Sembiring, M.G. (2013) 'Visualizing impending features shaping persistence viewed by Universitas Terbuka students at Denpasar Regional Office', paper presented at The 25th International Council for Open and Distance Education World Conference, Tianjin, China, 16-18 October.

Sembiring, M.G. (2013) 'Predicting overall students' persistence behold by graduates', paper presented at The 26th Asian Association of Open Universities Annual Conference, Allama Iqbal Open University, Islamabad, Pakistan, 1-3 October.

Sembiring, M.G. (2015) 'Validating student satisfaction related to persistence, academic performance, retention, and career advancement within ODL perspectives', Open Praxis, Vol. 7, No. 4, pp.311-323, ICDE Prizes for Innovation and Best Practice, 2nd ed.

Sembiring, M.G. (2017) 'Exploratory study of academic excellence associated with persistence in ODL setting', Emerald Asian Association of Open Universities Journal, Vol. 12, No. 2, pp.125-136 [online] https://doi.org/10.1108/AAOUJ-01-2017-0015.

Sugiyono (2012) Metode Penelitian Kombinasi, Penerbit Alfabeta, Bandung, Indonesia.

Tinto, V. (1975) 'Dropout from higher education: a theoretical synthesis of research', Review of Educational Research, Vol. 45, No. 1, pp.89-125.

Tjiptono, F. and Chandra, G. (2011) Service, Quality and Satisfaction, Penerbit Andi, Yogyakarta, Indonesia.

Universitas Terbuka (2014) Strategic and Operational Planning of Universitas Terbuka 2014-2021, Universitas Terbuka, Tangerang Selatan, Indonesia.

Universitas Terbuka (2017) Yearly Report of the Rectorate Office for 2016, Universitas Terbuka, Tangerang Selatan, Indonesia.

Wijayanto, S.H. (2008) Structural Equation Modelling - Lisrel 8.80, Penerbit Graha Ilmu, Yogyakarta, Indonesia.

Yang, D., Baldwin, S. and Snelson, C. (2017) 'Persistence factors revealed: students' reflections on completing a fully online program', Distance Education, Vol. 38, No. 1, pp.23-36 [online] https://doi.org/10.1080/01587919.2017.1299561 (accessed 18 February 2018). 